ISSN 2414-1143

Научный альманах стран Причерноморья. 2018. Том 15. № 3

DOI 10.23947/2414-1143-2018-15-3-37-46

UDC 314.15

\title{
THE TOPICAL ISSUES OF POPULATION POLICY IN THE CRIMEAN FEDERAL DISTRICT
}

\author{
(CNataliia A. Ageeva, Galina N. Shapoval \\ Rostov State Medical University, Rostov-on-Don, Russian Federation \\ nataliya.ageeva@mail.ru, sgalinka@rambler.ru
}

In the Russian Federation the task of providing conditions for sustainable demographic development of the country has been priority for many years. On the 9th of October, 2007 the Conception of the population policy of the Russian Federation until 2025 was approved by the Decree of the President of Russia. The plan of its realization measures has already given favorable results. In 2017 the selective observation of reproductive plans of the population was held in the territory of the Crimean Federal District. The census has revealed the general ideas of desires and fears of men and women connected with starting a family and the birth of the first and the next children. This information has given the chance for development of a complex of the actions focusing on improvement of birth rate indicators and decrease of mortality indicators. The article considers the effective measures for stimulation of birth rate and promoting of family values among young people, since the period of their studies at college and at the university: celebration in honor of professional dynasties and young families, congratulation them on wedding and child's birth, providing young parents with benefits, etc. Measures, focusing on material support of large families: improvement of qualities of life and health care, possibility of self-realization and career development will be in demand among middle-aged people. The state national security directly depends on achievements of population policy of the state that is realizable only in the context of creation of conditions for full development of the personality and efficiency of activity of all citizens of the country. The authors consider that the people confident in future will build closeknit families and implement their reproductive plans without fear.

Key words: population policy, health care, Crimean Federal District, reproductive plans, family values.

\section{[Н.А. Агеева, Г.Н. Шаповал Актуальные вопросы демографической политики в Крымском федеральном округе]}

В Российской Федерации многие годы является приоритетной задача по обеспечению условий для устойчивого демографического развития страны. 9 октября 2007 года Указом Президента РФ была утверждена Концепция демографической политики Российской Федерации на период до 2025 года. План мероприятий по её реализации уже дал благоприятные результаты. В 2017 году на территории Крымского фредерального округа было проведено выборочное наблюдение репродуктивных планов населения. Данные переписи раскрыли общие представления о желаниях, опасениях и страхах мужчин и женщин, связанных с созданием семьи и рождением первого и последующих детей, дали возможность для разработки комплекса мероприятий, направленных на улучшение показателей рождаемости и снижения показателей смертности. В статье рассматриваются эффрективные меры по стимулированию рождаемости и популяризации семейных ценностей у молодёжи, начиная с периода обучения в колледже и университете: чествование профессиональных династий и молодых семей, поздравление их со свадьбой, рождением ребёнка, предоставление льгот молодым родителям и т.д. У людей среднего возраста будут востребованы меры, направленные на материальную поддержку многодетных семей: улучшение качества жизни и медицинского обслуживания, возможность самореализации и карьерного роста. Национальная безопасность страны напрямую зависит от успехов демографической политики государства, что реализуемо только в контексте создания условий для полноценного развития личности $и$ эфрфективности жизнедеятельности всех граждан страны. Авторы считают, что люди, уверенные в завтрашнем дне, без опаски будут строить крепкие семьи и реализовывать свои репродуктивные планы.

Ключевые слова: демографрическая политика, здравоохранение, Крымский федеральный округ, репродуктивные планы, семейные ценности. 
Nataliia A. Ageeva, - candidate of philosophy, associate professor. Rostov State Medical University. Rostovon-Don, Russian Federation.

Агеева Наталия Алексеевна - кандидат философских наук, доцент. Ростовский государственный медицинский университет. г. Ростов-на-Дону, Россия.

Galina N. Shapoval - candidate of philosophy, associate professor. Rostov State Medical University. Rostovon-Don, Russian Federation.

Шаповал Галина Николаевна - кандидат философьских наук, доцент. Ростовский государственный медицинский университет. г. Ростов-на-Дону, Россия.

The human capital is a strategic resource of each family, any professional community and state. The citizens' health of the Russian Federation, high living standard of the population, growth of the birth rate and reduction of mortality are success factors of the state population policy. The basis of human capital functioning at the individual and group levels is development of a toolbox on supplying conditions for sustainable demographic development of the country. According to the health conditionality model accepted by the World Health Organization $50-55 \%$ of health depends on lifestyle, $20-25 \%$ depends on environmental conditions, up to $15 \%$ depends on heredity, and not more than $15 \%$ depends on activities of health care agencies and institutions. Therefore, the reproduction of stocks of health among the majority of our country's population is possible by means of realization at the state and corporate levels of a toolbox supplying the leading healthy life by the citizens $[4$, p. 76$]$.

Scientists, doctors and teachers considered the problem of healthy lifestyle in conjunction with morality problem. For example, I.I. Mechnikov in his paper "Pessimism and optimism" noted: "... the personal morality consists in such behavior where the normal cycle of life leading to perhaps full sense of satisfaction which is achievable only in old age can take place. That is why we have the right to name the man wasting health and strength in his youth as a result depriving himself of the opportunity to feel the greatest satisfaction with life immoral" [12, p. 524].

The man's desires are often incommensurable with his opportunities, as a result there is pessimism and thirst for unhealthy habits. I.I. Mechnikov urged everybody to live according the laws of orthobiosis. The scientist developed the theory of correct life according to which "the greatest happiness consists in normal evolution of life sense leading to a quiet old age and, at last, to the sense of saturation by life" [12, p. 526]. The basis of orthobiosis is formed by the fight against disharmonies which includes: 1) correction of man`s physical disabilities and imperfections, 2) victory over the diseases shortening life, 3) counteraction to unhealthy habits, 4) hygiene, 5) social reorganizations, 6) creation of harmonious organism, which is completely in tune with the nature. The tendency of young people to pessimism can be an obstacle on this way: "The optimistic world view is connected with normal health while pessimism depends on some physical disease or mental illness" [12, p. 427].

I.I. Mechnikov pays great attention to science, medicine, education and individual's will in the process of formation of optimistic world view and personal morality. The scientist emphasized: "Scientific education is so necessary for moral behavior that ignorance should be referred to the most immoral phenomena" [12, p. 537]. He considered that morality in science has to promote achievement of an ideal which consists not only in physical and moral improvement of each individual, but also in achievement of new principles of human relationship. For this purpose people have to rise above anger and ignorance, cruelty and hatred, philistinism and antihumanity with the help of their mind. I.I. 
Mechnikov urged everybody to be engaged only in what is available for our mind: "The man is capable of great deeds; that is why it is necessary to wish him to change human nature and turn its disharmonies into harmonies. The man 's will alone can reach this ideal" [12, p. 546]. In modern Russian society, education systems and health care are able to develop the individual's optimistic relation to life and to develop man to full understanding of need of healthy lifestyle for the purpose of achievement of long, active and green old age.

At the beginning of the 20th century V.M. Bekhterev in his paper "The personality and conditions of its development and health" warned that "... ignorance and lack of education are the main condition of personality undevelopment" [7, p. 125]. Within our research we would like to consider physical conditions in details. Full personality development depends on these conditions: 1) the organism nature and its anthropological features, 2) the biological factor connected with conditions of impregnation and development of human organism, 3) the adverse economic conditions leading to physical weakening of organism, 4) unhygienic working conditions, overfatigue, lack of rest have harmful influence on personality development, 5) "intellectual poisons" (alcohol, opium, morphine, ester, etc.) the chronic poisonings damaging the man's brain (the dulled sensations, the lowered morality, the weakened will - these features characterize personality decline), 6) upbringing and personality education: the overloading the head by unnecessary knowledge, lack of their critical judgment, suppression of any glimmer of initiative and independence in pupils, - all this kills love to knowledge and ability to think independently in pupils and teachers, 7 ) lack of social work leads to insufficient personality development, 8) lack of correctly organized social work in the form of self-government which is shown in idleness and inactivity [7, pp. 112-121].

According to V.M. Bekhterev, normal personality development is provided by: 1) public sanitation (disease prevention, labor protection), 2) fight against biological factors of degeneration (regulated marriage, forbidding to marry the insane, epileptics, serious hysterics, neuropaths and chronic alcoholics), 3) elimination of destructive to health distribution of alcoholic and other intoxicating drinks (fight against alcoholism), 4) improvement of economic situation of population (welfare of the masses of people), 5) creation of conditions for the population amateur activity and legally capable activity of the personality, 6) upbringing and education (complete development of the personality corporal and spiritual food), 7) free development of social work represents the best guarantee of correct and healthy development of the personality [7, pp. 122-131].

Human life is not a spontaneous self-development, but a long chain of consecutive events and decisions which at the time of their implementation, above all, depend on our will and only then, thanks to their consequences and retrospective comprehension find the nature of need and are perceived as such. Under the activity approach to the personality the destiny notion is treated as internal definiteness of individual life to which the very person gives direction and sense [1].

Artistic freedom of the destiny is the main of all freedoms of a man. Human life depends on the content and orientation of activity and on the predetermined outcome of his life-purpose search. The choice is a starting point of creative life as it supposes the search of life meaning and composition of fundamental and secondary plans and programs. "Life of each man is unique, and therefore the meaning of life is individual at least three times: its subject-bearer is always unique, the situation in which the man finds sense of his life is unique, and the way which the man goes to the finding of sense of his life is unique" [1, p. 81].

In youth each man imagines life which he will have, drawing an ideal image of the future: family, number of children, character traits of a husband and a wife, career, etc. In 
2017 in the territory of the Crimean Federal District selective observation of reproductive plans of population [8] was held in accordance with: Resolution of the Government of the Russian Federation of 27 November, 2010 No. 946 "About the organization in the Russian Federation the system of federal statistical observations on social and demographic problems and monitoring of economic losses from deaths, incidence of disease and population disablement" and the plan of measures to implement in 2016-2020 the Conception of the population policy of the Russian Federation until 2025. Selection was formed on the basis of territorial selection of universal purpose on the basis of information collection of All-Russian Population Census of 2010.

In order to comply with the condition of voluntary consent of respondents to participation in poll two forms of federal statistical observation have been developed: 1) the questionnaire for a household (a form No. 1 - reproductive plans), 2) the individual questionnaire for women at the age of 18-44 and men at the age of 18-60 (a form No. 2 reproductive plans). Thanks to specially developed methodology, the outcomes of observation results have been spread to all private households and all population of the Crimean Federal District [8].

During the poll, data of age and sex list of respondents have been obtained: 1) women up to 25 years $-14,9 \%, 25-29$ years $-16,7 \%, 30-34$ years $-22,0 \%, 35-39$ years $21,9 \%, 40$ years and over - 24,6\%; 2) men up to 25 years - 9,9\%, 25-29 years - 12,0\%, $30-34$ years $-15,1 \%, 35-39$ years $-14,0 \%, 40$ years and over $-49,0 \%$. It means that women up to 40 years $(75,5 \%)$ and men up to 40 years and over $(49,0 \%)$ took part in observation actively. Most of respondents have education: secondary vocational education - 33,1\% (women) and 44,2\% (men), higher professional education $-45,4 \%$ (women) and $28,6 \%$ (men).

During the research the share of unmarried women and men is defined. High rates have been received among women up to 25 years $-38,6 \%$ and among men up to 25 years $-46,7 \%$. Slightly lower indicators among women of $25-29$ years $-20,0 \%$ and among men of $25-29$ years $-22,3 \%$. The obtained data demonstrate that most of the interviewed women and men up to 29 years live in an unregistered marriage that can have a negative impact on their reproductive plans. The high percent of the people living in the unregistered marriage demonstrates the spiritual crisis which has struck modern society and which has destroyed family values in understanding of the majority. The prescription "At first it is necessary to live together, and then to register marriage" was supported by more than $40 \%$ of the interviewed women which have from the primary general education to the higher professional education. The men have the same opinion; the data of the poll differ from $40 \%$ to $59 \%$ depending on their education. It is troubling that the women consisting in the unregistered marriage are going to register it: in the absence of pregnancy $38,5 \%$ have answered "no", $20,7 \%$ have answered "it is hard to say", in case of pregnancy till the child`s birth $29,1 \%$ have answered "no", $14,1 \%$ have answered "it is hard to say", after the child`s birth $28,9 \%$ have answered "no", $15,8 \%$ have answered "it is hard to say".

The received results indicate lack of confidence among women in the fortress and viability of "partnership" that has a negative impact on dynamics of the solution of demographic problems in the specific region of our country. In general, $59,2 \%$ of respondents have declared that they don't want to register marriage in the absence of pregnancy [8]. Unfortunately, consumer orientation of character is inherent in most of modern individuals regardless of age and sex distinctions, the social status, education level and the territory of living. Such people live in a mode of "Possession" (according to E. Fromm), having a dominant "on his face" (the situation of self-affirmation and selfish highhandedness) (according to A.A. Ukhtomsky). They aspire to the comfort and don't 
wish to sacrifice anything (time, money, attention, sympathy) for the sake of other person (husband/wife, father/mother, brother/sister, and son/daughter). Such respondents consider the relation in the unregistered marriage "without stamps and obligations", the birth and upbringing of the children in incomplete families to be a norm. We can measure the crisis of family values by the number of divorces and abortions, abandoned old men and children.

At the same time, in modern society there are a lot of individuals with productive orientation of character living in a mode of "Life" (according to E. Fromm), having a dominant "on the face of another" (the situation of responsible attention to people and real contact with them) (according to A.A. Ukhtomsky). These people love and are friends with other people sincerely, without adultery and treacheries. They are ready to self-sacrifice for the sake of the interests of the closest, loved, dear person. The men and women having productive orientation of character work "for the result" which doesn 't consist in material benefit for themselves, this result has the purpose to realize the cultural wealth which is shown in love, friendship, a healthy lifestyle, patriotism, kind deeds and justice in relation to other people.

Society, culture, family are indissoluble. The culture of the family is a development and formation of the personality in honoring of true values of the people. In the conditions of spiritual crisis in society most of people perceive forms of distorted love as a norm. The reasons are the following: atheistic upbringing of the last century and neglect of religious and cultural traditions of the people. Love is a great gift. Ascension to love has a long way in time: from enthusiastic love, through trials and difficulties to true love. The position and level model of man and woman relations shows the relation orientation on the positional bases, they are a core of "ego desires" and a core of "conscience". Conscience is a basis for manifestation of true love. Ego desires are the basis for the distorted manifestation of love between a man and a woman. Behavior, needs, aspirations of an ego desire are defined by a lexical formula "for your own sake". The activity happening out of respect for a debt and conscience is expressed by a formulation "for the sake of another" [11, p. 55].

In our opinion, the state population policy should aim at spiritual and moral crisis overcoming by promoting of family values and formation of high level of sense of justice among children and young people.

Last 10 years the actions for the birth rate stimulation have been implemented in the Russian Federation actively. The social and economic aspect in the solution of demography problems was always in the priority. Social benefits, improvement of living conditions, support of young and large families, and improvement of medical assistance quality contribute to the decrease of number of abortions and to the birth rate increase. However, it shouldn't be forgotten about death rate and invalidization among the population. It is known that use of contraception and induced abortion can become the reason of diseases of woman's urogenital system and her infertility [5, p. 34]. According to the statistical data, the share of women using contraception before their first child was born is the following: up to 25 years $-48,8 \%, 25-29$ years $-38,0 \%, 30-34$ years $-37,0 \%$, $35-39$ years $-35,4 \%, 40$ years and over $-31,7 \%$. It is troubling that a share of women who had abortions is the following: up to 25 years $-12,9 \%, 25-29$ years $-20,1 \%, 30-34$ years $-30,1 \%, 35-39$ years $-37,9 \%, 40$ years and over $-45,5 \%$. These are high rates taking into consideration that in each age category was approximately from $9,5 \%$ to $15,4 \%$ of women who have refused to answer this question. At the same time, the share of men using contraception is also high: up to 25 years - 10,4\%, 25-29 years $-28,8 \%, 30-34$ years - 40,4\%, 35-39 years - 44,9\%, 40 years and over - 44,8\%. Considering the multinational and multi-religious population composition of the Crimean Federal District, in the solution of questions of demography and abortions prevention it is necessary to involve 
all educational and medical institutions, leaders of clergy and civil society, culture and media actively.

The role of sociocultural samples in formation of healthy lifestyle is very significant. Heavy responsibility lies on teachers of teacher training and medical colleges and higher education institutions which by their own example should promote personal growth of students as future experts of education systems and health care. It is justified because in professional activities it will necessary for teachers and doctors to be engaged in promoting of their pupils and patients healthy lifestyle [2-6]. However, it shouldn't be forgotten about the leading role of media in the course of images replication of vital success to the masses.

Pompous vanity, imitation of vital processes, hedonism and consumerism have become a style of modern postmodernism. Negative qualities of human personality (aggression, mercenariness, lasciviousness, impudence, fraud, etc.) are cultivated in society as ways of achievement of success in life. Promotion of vice as a social norm doesn't promote creation and preservation of successful families. In a similar situation there is a contradiction between desirable and due. Without family happiness vital success can't be a really achieved result. That's why society can and has to create such sociocultural samples which, besides attractiveness, will bring high sense and moral values to the masses. For the benefit of ensuring national security of Russia it is necessary to direct mass impact of communication to the necessary course: for the personality all-round development, revival of spiritual and moral bases of society; healthy lifestyle promoting, development of critical thinking and cultural and enlightening abilities of children and young people. The problems of students' socialization are broached in a number of published papers [9, 10, 13, 15, 16].

The priority problem of Strategy of national security of the Russian Federation approved 31.12.2015 is "increase of lifetime, decrease of level of disablement and mortality of the population, increase of number of inhabitants" [14, p. 26]. In dealing with the demographic problems the early detectability of oncological diseases of women reproductive system by means of medical examination (the system of oncology screening once in two years) and annual gynecological examinations (suprasonic, cytologic, microbiological) is important. Every year the quantity of the oncological diseases detected among women during pregnancy increases. For modern women it is one of fear factors of the birth of the first child and the next children [3, p. 40]. Distribution of respondents according to the number of born children is the following: $29,9 \%$ of women and $32,2 \%$ of men have no children, one child among $36,8 \%$ of women and $30,6 \%$ of men, 2 children among $26,5 \%$ of women and $29,2 \%$ of men, three children among $5,5 \%$ of women and $6,4 \%$ of men, four children among $1,0 \%$ of women and $1,2 \%$ of men, five and more children among $0,4 \%$ of women and $0,5 \%$ of men. The interviewed respondents on average want to have one or two children. Assessment of possible influence of one more child appearance on various aspects of activity among uniparous women and men revealed fears of respondents by deterioration of: 1) financial family position among $59,9 \%$ of women and $54,8 \%$ of men, 2) living conditions among $33,6 \%$ of women and $31,3 \%$ of men, 3) opportunities to have a good rest among $41,6 \%$ of women and $37,7 \%$ of men. Respondents with two children also pointed to the same criteria for evaluation of family living standards [8].

Assessment of influence of additional measures of the state support of families with children on the decision concerning the child's birth after 01.01.2007 revealed that these measures helped to appear the child whose birth in the family was postponed as the family could not afford it: the first child among $27,8 \%$ of women and $28,8 \%$ of men, the second child among $44,2 \%$ of women and $39,5 \%$ of men, the third child among $48,8 \%$ of women 
and $39,6 \%$ of men [8]. These are good indicators, but the Government of the Russian Federation has a room for improvement, financing old and developing new additional measures of the state support of families with children.

Certainly, it is necessary to stimulate birth rate and to popularize family values among young people since the studentship, giving to young parents an opportunity to be accepted to State-funded places or to be transferred from commercial to free education. Since the period of studying at college and university, young people should feel the priority of solution of demographic problems in all manifestations of student's life. Students should be involved in process in which they honor professional dynasties and young families, congratulate them on wedding and child's birth. Options for providing young parents with benefits should be explained for them. It can be used as an element of educational work of dean's offices and real work of trade-union committees and student trade-union committees of educational institution. Employees and students of colleges and universities should feel unification with each other, being together not only in hard times (disease and death), but also in happiness (wedding and child's birth). It does not require special material costs, but effectively exercises a soul in mercy, serves mobilization of forces of civil society in family values preservation and birth rate increase not only in separately taken educational institution, but also in general in the region and around the country.

It is also possible to support young mothers who decided to give birth to a baby during their studies, having created in the territory of colleges and universities departmental kindergartens (mixed age groups of children of preschool age) which functioning will be carried out on the basis of interdepartmental interaction with the participation of students of medical and pedagogical institutions doing there pediatric and teaching traineeships. It will promote not only simplification of young mothers' life and continuation of their studies, but also successful socialization of all students in general, by means of practical development of professional activity basics.

Middle-aged people are interested in measures, focusing on improvement of qualities of life and health care, possibility of self-realization and career development, material support of large families. It is necessary to add points of development and implementation of additional measures of the state support of families with children into effective contracts of government employees. In regions it is necessary to build social housing funded by the state, to give it to young families and single mothers and after the birth of the third child to provide them with this housing by right of ownership.

The results of selective observation of reproductive plans of the population of the Crimean Federal District showed that in the conditions of spiritual crisis of modern society most of young people do not seek to start families and to take the responsibility, to fulfill certain duties, to respect the rights and dignity of the loved one. All this demonstrates prevalence of consumer orientation in society. In our opinion, the way out of this deadlock is family values revival, healthy lifestyle promotion and familiarizing of young generation with cultural and religious traditions of the people. In the solution of demographic problems of the present the concern of the State about citizens also plays an important role as optimistically reproductive plans are made by the healthy happy and confident in future people.

\section{Лumepamypa}

1. Агеева Н.А. Идея судьбы в противостоянии мифологического и рационального мышления: дис. канд. филос. наук: Ростов-на-Дону, 2004. 112 с.

2. Агеева Н.А. Коррупция в системе здравоохранения РФ как уродливая форма правосознания индивидов. Гуманитарные и социальные науки. 2014. № 1. С. 48-56. 
3. Агеева Н.А. Психофизические особенности онкологических больных в контексте биоэтических проблем современности. Гуманитарные и социальные науки. 2013. № 4. С. 35-43.

4. Агеева Н.А. Социокультурные и психолого-педагогические аспекты профилактики алкоголизма и наркомании в Российской Федерации. Наркология. 2016. Т. 15. № 6 (174). С. 76-83.

5. Агеева Н.А. Этико-правовые аспекты аборта. Гуманитарные и социальноэкономические науки. 2014. № 2. С. 33-37.

6. Агеева Н.А., Шаповал Г.Н. Решение ситуационных задач как эффективный метод формирования у студентов-медиков навыков этико-правового измерения медицинской деятельности. Личность в меняющемся мире: здоровье, адаптация, развитие. 2017. Т. 5. № 4 (19). С. 598-637.

7. Бехтерев В.М. Проблемы развития и воспитания человека / под ред. А.В. Брушлинского и В.А. Кольцовой. М.: Институт практической психологии, Воронеж: МОДЭК, 1997. 416 с.

8. Выборочное наблюдение репродуктивных планов населения 2017 [Электрон-

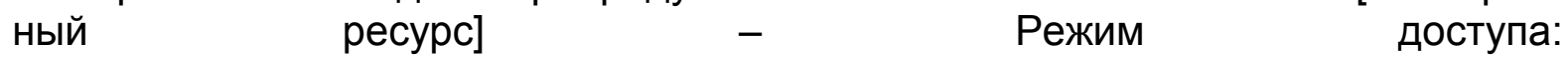
http://www.gks.ru/free_doc/new_site/RPN17/index.html (дата обращения 29.07.2018).

9. Камалова О.Н., Шаповал Г.Н. К вопросу о нравственном воспитании российских и иностранных студентов, обучающихся вместе. Гуманитарные и социальные науки. 2014. № 2. С. 378-381.

10. Карташова Е.А., Шаповал Г.Н. Этика ответственности за сохранение жизни: общечеловеческий и философский аспекты биоэтики. Современные исследования в сфрере социальных и гуманитарных наук. Сборник результатов научных исследований. Киров, 2018. С. 383-387.

11. Культура семьи: Учебное пособие. Москва, 2009. 184 с.

12. Мечников И.И. Пессимизм и оптимизм. М.: Сов. Россия, 1989. 640 с.

13. Толмачев В.Г., Шаповал Г.Н. Philosophy and ethics of conservation of life. Cовременные исследования в сфрере социальных и гуманитарных наук. Сборник результатов научных исследований. Киров, 2018. С. 510-513.

14. Утверждена Стратегия национальной безопасности России / [Электронный ресурс]. - Режим доступа. - URL: http://www.kremlin.ru/acts/news/51129 (дата обращения 29.07.2018).

15. Шаповал Г.Н. Образы зла в художественной культуре: дис. канд. фрилос. наук: Ростов-на-Дону, 2002. 166 с.

16. Shapoval G.N. Foreign medical students adaptation in the conditions of humanization and humanitarization of higher education. Научный альманах стран Причерноморья. 2016. № 1 (5). С. 41-43.

\section{References}

1. Ageeva N.A. Ideia sud'by v protivostoianii mifologicheskogo i ratsional'nogo myshleniia [The idea of destiny in opposition of mythological and rational thinking]. Dissertation of candidate of philosophical sciences: Rostov-on-Don, 2004. 112 p. (in Russian).

2. Ageeva N.A. Korruptsiia v sisteme zdravookhraneniia RF kak urodlivaia forma pravosoznaniia individov [Corruption in a health care system of the Russian Federation as an ugly form of sense of justice of individuals]. Gumanitarnye i sotsial'nye nauki [Humanitarian and social sciences]. 2014. No. 1. pp. 48-56 (in Russian). 
3. Ageeva N.A. Psikhofizicheskie osobennosti onkologicheskikh bol'nykh v kontekste bioeticheskikh problem sovremennosti [Psychophysical features of oncological patients in the context of bioethical problems of the present]. Gumanitarnye i sotsial'nye nauki [Humanitarian and social sciences]. 2013. No. 4. pp. 35-43 (in Russian).

4. Ageeva N.A. Sotsiokul'turnye i psikhologo-pedagogicheskie aspekty profilaktiki alkogolizma i narkomanii v Rossiiskoi Federatsii [Sociocultural and psychology and pedagogical aspects of prevention of alcoholism and drug addiction in the Russian Federation] Narkologiia [Narcology]. 2016. Vol. 15. No. 6 (174). pp. 76-83 (in Russian).

5. Ageeva N.A. Etiko-pravovye aspekty aborta [Ethic and legal aspects of abortion]. Gumanitarnye i sotsial'no-ekonomicheskie nauki. [Humanitarian, social and economic sciences]. 2014. No. 2. pp. 33-37 (in Russian).

6. Ageeva N.A., Shapoval G.N. Reshenie situatsionnykh zadach kak effektivnyi metod formirovaniia u studentov-medikov navykov etiko-pravovogo izmereniia meditsinskoi deiatel'nosti. Lichnost v meniaiushchemsia mire: zdorov'e, adaptatsiia, razvitie [The solution of situational tasks as an effective method of formation of skills of ethic and legal measurement of medical activity among medical students. The personality in the changing world: health, adaptation, development]. 2017. Vol. 5. No. 4 (19). pp. 598-637(in Russian).

7. Bekhterev V.M. Problemy razvitiia i vospitaniia cheloveka pod red. A.V. Brushlinskogo i V.A. Kol'tsovoi [Problems of development and education of the person under the editorship of A.V. Brushlinsky and V.A. Koltsova] Moscow: Institute of practical psychology, Voronezh: research and manufacturing association MODEK, 1997. 416 p. (in Russian).

8. 8. Vyborochnoe nabliudenie reproduktivnykh planov naseleniia [Selective observation of reproductive plans of the population of 2017]. Available at: http://www.gks.ru/free_doc/new_site/RPN17/index.html (Accessed 29 July 2018).

9. Kamalova O.N., Shapoval G.N. K voprosu o nravstvennom vospitanii rossiiskikh i inostrannykh studentov, obuchaiushchikhsia vmeste [To the question of moral education of the Russian and foreign students studying together]. Gumanitarnye i sotsial'nye nauki.[Humanitarian and social sciences]. 2014. No. 2. pp. 378-381 (in Russian).

10. Kartashova E.A., Shapoval G.N. Etika otvetstvennosti za sokhranenie zhizni: obshchechelovecheskii i filosofskii aspekty bioetiki. Sovremennye issledovaniia v sfere sotsial'nykh i gumanitarnykh nauk [Ethics of responsibility for preservation of life: universal and philosophical aspects of bioethics. Modern researches in the sphere of social and the humanitarian sciences]. Sbornik rezultatov nauchnykh issledovanii [Collection of results of scientific researches]. Kirov, 2018. pp. 383-387 (in Russian).

11. Kultura semi: Uchebnoe posobie. [Culture of family: Education guidance]. Moscow, 2009. 184 p. (in Russian).

12. Mechnikov I.I. Pessimizm i optimizm [Pessimism and optimism]. Moscow: Soviet Russia, 1989. 640 p. (in Russian).

13. Tolmachev V.G., Shapoval G.N. Philosophy and ethics of conservation of life. Sovremennye issledovaniia $v$ sfere sotsialnykh i gumanitarnykh nauk [The modern researches in the sphere of social and the humanitarian sciences]. Sbornik rezul'tatov nauchnykh issledovanii [Collection of results of scientific researches]. Kirov, 2018. pp. 510-513. 
14. Utverzhdena Strategiia natsional'noi bezopasnosti Rossii [The Strategy of the national security of Russia is approved]. Available at: http://www.kremlin.ru/acts/news/51129 (Accessed 29 July 2018).

15. Shapoval G.N. Obrazy zla v khudozhestvennoi kulture: dis. kand. filos. Nauk [Images of the evil in artistic culture: dissertation of candidate of philosophical sciences]. Rostov-on-Don, 2002. 166 p. (in Russian).

16. Shapoval G.N. Foreign medical students' adaptation in the conditions of humanization and humanitarization of higher education. Science almanac of Black Sea region countries. 2016. No. 1 (5). pp. 41-43. 